\title{
BLASTOCYST TRANSFER STUDY IN THE SENESCENT GOLDEN HAMSTER
}

\author{
B. A. STOCKTON, T. A. PARKENING AND A. L. SODERWALL \\ Department of Biology, University of Oregon, \\ Eugene, Oregon 97403, U.S.A.
}

(Received 28th Fuly 1972)

\begin{abstract}
Summary. Blastocysts and late morulae were flushed from the uteri of young female donors (3- to 6-month-old) at 62 to 67 hours after ovulation and were transferred to the uteri of young (4- to 6-month-old) and senescent (14- to 15-month-old) pseudopregnant female hamsters 62 to $67 \mathrm{hr}, 86$ to $91 \mathrm{hr}$, or 110 to $115 \mathrm{hr}$ after ovulation The highest percentage of ovum implantation and the greatest number of females with implantation sites were noted in the young female after ova were transferred 62 to $67 \mathrm{hr}$ after ovulation and in the senescent female following transfers 86 to $91 \mathrm{hr}$ after ovulation. This indicates a possible delay in uterine receptivity to blastocyst implantation in the senescent hamster and may contribute to the reduction in litter size noted in the senescent female.
\end{abstract}

Reproductive senescence is manifested in the golden hamster female by a reduction in mean litter size, an increase in the gestation period and a decrease in the capacity to bear living young (Soderwall, Kent, Turbyfill \& Britenbaker, 1960). Blaha (1964a) noted that the old female had a smaller area of decidualization associated with the implanting blastocyst. The senescent female showed poor deciduomata formation under conditions which yielded good results in the young hamster (Blaha, 1967). Connors (1969) found that the senescent hamster exhibited a delay of $12 \mathrm{hr}$ in forming decidual cells during pregnancy.

These data prompted this study in which blastocysts and late morulae were flushed from young donors ( 3 to 6 months old) and were transferred to young (4- to 6-month-old) and senescent (14- to 15-month-old) hosts on Day 3 (62 to $67 \mathrm{hr}$ after ovulation), Day 4 (86 to $91 \mathrm{hr}$ after ovulation) or on Day 5 (110 to $115 \mathrm{hr}$ after ovulation) of pseudopregnancy. Pseudopregnancy was induced by mating with vasectomized males on the evening of behavioural oestrus. The oestrous cycle was followed by daily checks of vaginal secretion (Orsini, 1961). Day 1 of pseudopregnancy was taken as the day after mating.

The uteri of donor females were flushed 62 to $67 \mathrm{hr}$ after ovulation with $37^{\circ} \mathrm{G}$ Hanks's Balanced Salt Solution. Ova were examined and those which appeared normal were separated into two equal groups ( \pm one ovum). Transfers were carried out using a Hamilton Gas-Tight syringe attached to a $\frac{3}{4}$ inch, 27-guage, siliconized needle. A bubble of air above the transfer medium served as a

* Present address: Department of Biology, Tabor College, Hillsboro, Kansas 67063. 
'marker' for the ova. The reproductive tract was exposed through a dorsolateral incision in the body wall. The ova in 0.01 to $0.02 \mathrm{ml}$ transfer medium were introduced into the uterine lumen at the uterotubal junction.

Recipients were killed 4 to 5 days after the transfers had been effected, and their uteri were removed, fixed and cleared according to the method of Orsini (1962). Table 1 gives the results of this study. These data were analysed using the $\chi^{2}$ test with a $2 \times 2$ Contingency Table (Campbell, 1967).

Within the populations, significant differences were found in (a) the number of females reacting and (b) the number of implantation sites for (1) young, Day 3 versus Day $4\left(P_{\mathrm{a}}<0.05 ; P \mathrm{~b}_{\mathrm{b}}<0.005\right),(2)$ senescent, Day 3 versus Day $4\left(P_{\mathrm{a}}<\right.$ $\left.0.05 ; P_{\mathrm{b}}<0.05\right)$ and (3) senescent, Day 4 versus Day $5\left(P_{\mathrm{a}}<0.001 ; P_{\mathrm{b}}<0.001\right)$.

There appears to be a delay in the maximum uterine sensitivity to blastocyst implantation in the senescent female. Synchrony of embryonic development and uterine development before implantation has been shown to be important

Table 1. Synchronous and asynchronous blastocyst transfers in young and old hamsters

\begin{tabular}{c|c|c|c}
\hline $\begin{array}{c}\text { Age status } \\
\text { (and total no. }) \\
\text { of recipient } \\
\text { females }\end{array}$ & $\begin{array}{c}\text { Time of transfer } \\
\text { day of pseudo- } \\
\text { pregnancy (hours } \\
\text { after } \\
\text { ovulation) }\end{array}$ & $\begin{array}{c}\text { No. of implantation } \\
\text { sites/no. of ova } \\
\text { transferred }\end{array}$ & $\begin{array}{c}\text { Females with } \\
\text { implantation } \\
\text { sites }\end{array}$ \\
\hline Y (14) & $3(62$ to 67$)$ & $20 / 122(16.4 \%)$ & 8 \\
S (9) & $4(86$ to 91$)$ & $11 / 96(11.5 \%)$ & 3 \\
Y (10) & $3 / 95(3.2 \%)$ & 1 \\
S (10) & $5(110$ to 115$)$ & $22 / 94(23.4 \%)^{* *}$ & $8 / 91$ \\
Y (9) & $0 / 77$ & 0 \\
S (9) & & 0 & 0 \\
\hline
\end{tabular}

All ova used in transfer were flushed during Day 3 of pseudopregnancy (62 to $67 \mathrm{hr}$ after ovulation). $\mathrm{Y}$-young female: S-senescent female.

* Statistically significant, $P<0.005$.

** Statistically significant, $P<0.001$.

in rats (Noyes \& Dickmann, 1960; Dickmann \& Noyes, 1960), in mice (McLaren \& Michie, 1956; Doyle, Gates \& Noyes, 1963) and in rabbits (Chang, 1950). Hertig (1967) reported a higher incidence of abnormal embryos from human females when ovulation occurred after the 14th day of the menstrual cycle.

From the results of blastocyst transfer studies, ova from old hamsters hàve been reported as less viable than those from young females (Blaha, 1964b). A combination of less viable ova with a delay in uterine sensitivity to blastocyst implantation could account, in part, for the decrease in mean litter size seen in the senescent female hamster.

This study was supported by Public Health Service Grant 5-R01-HD04234-03.

\section{REFERENCES}

BLAHA, G. C. (1964a) Reproductive senescence in the female golden hamster. Anat. Rec. 150, 405. 
BtAHA, G. C. (1964b) Effect of age of the donor and recipient on the development of transferred golden hamster ova. Anat. Rec. 150, 413.

BLAHA, G. C. (1967) Effects of age, treatment and method of induction of deciduomata in the golden hamster. Fert. Steril. 18, 477

Campbelt, R. G. (1967) Statistics for biologists, p. 62. Cambridge University Press.

Chang, M. G. (1950) Development and fate of transferred rabbit ova or blastocyst in relation to the ovulation time of recipients. F. exp. Zool. 114, 197.

Connors, T. J. (1969) Reproductive senescence in the golden hamster: early development and implantation of the blastocyst. Ph.D. dissertation, University of Oregon, Eugene, Oregon.

Drckmans, Z. \& Noyes, R. W. (1960) The fate of ova transferred into the uterus of the rat. F. Reprod. Fert. 1, 197.

Doyle, L. L., Gates, A. H. \& Noyes, R. W. (1963) Asynchronous transfer of mouse ova. Fert. Steril. $14,215$.

Hertic, A. T. (1967) The overall problem in man. In: Comparative Aspects of Reproductive Failure, p. 11. Ed. K. Bernirschke, Springer, New York.

MaLaren, A. \& Michie, D. (1956) Studies on the transfer of fertilized mouse eggs to uterine foster mothers. I. Factors affecting implantation and survival of native and transferred eggs. F. exp. Biol. 33, 394.

Noyes, R. W. \& Dickmann, Z. (1960) Relationship of ovular age to endometrial development. $\mathcal{F}$. Reprod. Fert. 1, 186.

OrsinI, M. W. (1961) The external vaginal phenomena characterizing the stages of the estrous cycle, pregnancy, pseudopregnancy, lactation and the anestrus hamster (Mesocricetus auratus, Waterhouse). Proc. Anim. Care. Panel, 11, 193.

ORSINI, M. W. (1962) Technique of preparation, study and photography of benzyl-benzoate cleared material for embryological studies. F. Reprod. Fert. 3, 283.

Soderwall, A. L., Kent, H. A., Turbyfill, G. L. \& Britenbaker, A. L. (1960) Variation in gestation length and litter size of the golden hamster, Mesocricetus auratus. F. Geront. 15, 246. 